\title{
OFF-BALANCE SHEET ACTIVITIES OF THE CZECH BANKING SECTOR
}

\section{Veronika Bučková}

\section{Klíčová slova:}

komerční banka, mimobilanční aktivity, rozvaha, HDP, př́ijem z poplatků a provizí

\section{Key words:}

commercial bank, off-balance sheet activities, balance sheet, GDP, fee and commission income

\begin{abstract}
Abstrakt
Příspěvek je zaměřen na mimobilanční aktivity komerčních bank působících $\mathrm{v}$ českém bankovním sektoru. Cílem př́spěvku je nalézt charakteristické znaky mimobilančních aktivit bankovního sektoru České republiky. První část př́spěvku obsahuje popis podrozvahových položek a vysvětluje, jaké existují typy mimobilančních operací. Další část je věnována agregované podrozvaze bankovního sektoru České republiky a je v ní provedena analýza struktury agregované podrozvahy. V následujících částech je provedena komparace mimobilančních a bilančních aktivit a je posouzena ziskovost mimobilančních aktivit. Obsahem poslední části prŕspěvku jsou mimobilanční aktivity $\mathrm{v}$ kontextu makroekonomického výstupu. Vědeckými metodami užitými $\mathrm{v}$ tomto př́spěvku jsou deskripce, komparace a analýza.
\end{abstract}

\begin{abstract}
This paper focuses on the off-balance sheet activities of the commercial banks in the Czech banking sector. The goal of the paper is to find out some characteristic features of the offbalance sheet activities of the Czech banking sector. The first part of the paper explains what the off-balance sheet items are and what types of off-balance sheet operations exist. The next part is devoted to the aggregate off-balance sheet of banking sector of the Czech Republic and the analysis of its structure. In the following parts the off-balance sheet is compared with the balance sheet and there is assessed the profitability of the off-balance sheet activities. The last part includes the off-balance sheet in the context of the macroeconomic output GDP. The scientific methods used in this research are the description, comparison and analysis.
\end{abstract}

\section{Introduction}

In the accounting of the banks, there are two important financial statements. The former is the balance sheet and the latter is the off-balance sheet. While the balance sheet includes bank's assets (that is what it owns) and its liabilities (that is its liabilities to its owners and external subjects), the off-balance sheet is consisted of possible assets and liabilities ${ }^{1}$. These assets and liabilities are not sure, but only probable. They just may become due.

Among the off-balance sheet activities, there can be involved various types of bank commitments and guarantees, trust services and spot or forward transactions. Except this, there can be involved different types of services, such as financial advisory or even providing payments. These services are not able to be caught in the bank's accounting.

\footnotetext{
${ }^{1}$ According to Dvořák, P. Bankovnictví pro bankéře a klienty.
} 
Definition of off-balance activities differs among authors. While some authors treat offbalance sheet activities only as the accounting receivable activities, some of them classify as off-balance sheet activities also payments, investment advisory, e-banking and other bank services. $^{2}$

The research is based mainly on the publicly available data from the Czech national bank (shortly "CNB") and the Ministry of Finance of Czech Republic. Except this, there are used some monographs and other sources from the Internet. All sources are listed in the end of the paper.

\section{Structure of the off-balance sheet ${ }^{3}$}

The structure of the off-balance sheet of commercial banks is based on the Decree on Accounting. ${ }^{4}$ No. 501/2002 Coll., implementing certain provisions of Act No. 563/1991 Coll., on Accounting, as amended, for accounting units that are banks and other financial institutions. Thus, particular items of the off-balance sheet are following:

- Commitments and guarantees given and received

- Pledge given and received

- Receivables and liabilities from spot transactions

- Receivables and liabilities from forward transactions

- Receivables and liabilities from options transactions

- Values given and received to asset management, custody and deposition

- Values given and received to maintenance

- Write-off receivables.

Like balance sheet, the off-balance sheet is divided into two parts - off-balance sheet assets and off-balance sheet liabilities. The structure of each part is in accordance with the Decree on Accounting mentioned above.

The OBS of commercial banks in the Czech Republic is typically made up especially by futures, forward, swap and options transactions. The share of futures, forward and swap transactions of off-balance sheet assets reaches approximately $80 \%$, in the case of OBS liabilities their share is about $56 \%$. These transactions are the most important OBS activities of all.

The commercial banks are allowed to show their spot transactions till the date of settlement on their off-balance sheet instead of balance-sheet. ${ }^{5}$ Generally, the banks prefer this method over the reporting spot transactions in their balance sheets. ${ }^{6}$ However, their share in the volume of off-balance sheet does not exceed $1 \%$.

\footnotetext{
${ }^{2}$ See Polouček, S. Bankovnictví. P. 424.

${ }^{3}$ Further in the text also shortly „OBS“.

${ }^{4}$ Decree No. 501/2002 Coll., implementing certain provisions of Act No. 563/1991 Coll., on Accounting, as amended, for accounting units that are banks and other financial institutions.

${ }^{5}$ The record of spot transactions on the off-balance sheet depends on the accounting approach choosen by the particular bank. In accordance with ,the approach of the trading day“, the traded asset is recorded immediately on the balance sheet and does not appear on the off-balance sheet. The second approach (which can be called „the approach of the settlement day“) is based on the temporal record of the traded asset on the off-balance sheet and after the settlement of the trade it is transferred on the balance sheet.

${ }^{6}$ Půlpánová, S. Komerční bankovnictví v České republice. P. 97.
} 


\section{Off-balance sheet assets}

Except of spot, futures, forward, swap and options transactions, the OBS assets include other items. However, their importance is not so high from the quantitative point of view. Tremendous part of the rest of OBS assets consists of commitments and guarantees given by banks to other subjects $(10 \%)$ and pledge given $(8 \%)$. Furthermore, there are other OBS assets in the form of write-off receivables, values given to asset management and values given to the custody. Their share is minimal (1-2\%).

The structure of OBS assets on December 31, 2009 is shown in Figure 1.

Fig. 1 Structure of off-balance sheet assets of the Czech banking sector on December 31, 2009 (in CZK millions and \%)

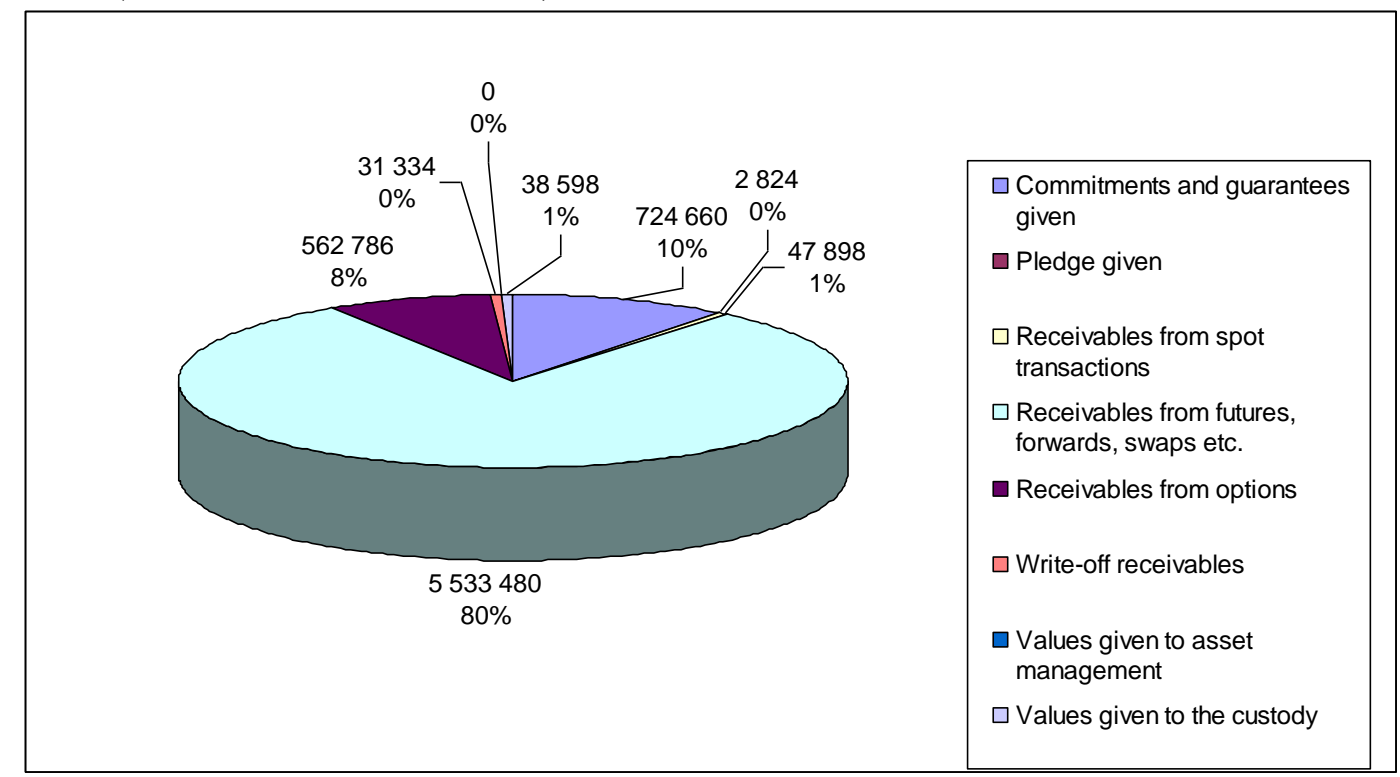

Source: own construction based on CNB's data

Off-balance sheet liabilities

Similarly, the OBS liabilities are created mainly by futures, forward and swap transactions, which represent various types of potential obligation to the bank $(56 \%)$. The second most important item is the pledge received (17\%) and values received to the custody $(15 \%)$. About $6 \%$ belongs to the options transactions and $5 \%$ to the received commitments and guarantees. The other items are negligible.

For more details see Figure 2. 
Fig. 2 Structure of off-balance sheet liabilities of the Czech banking sector on December 31, 2009 (in CZK millions and \%)

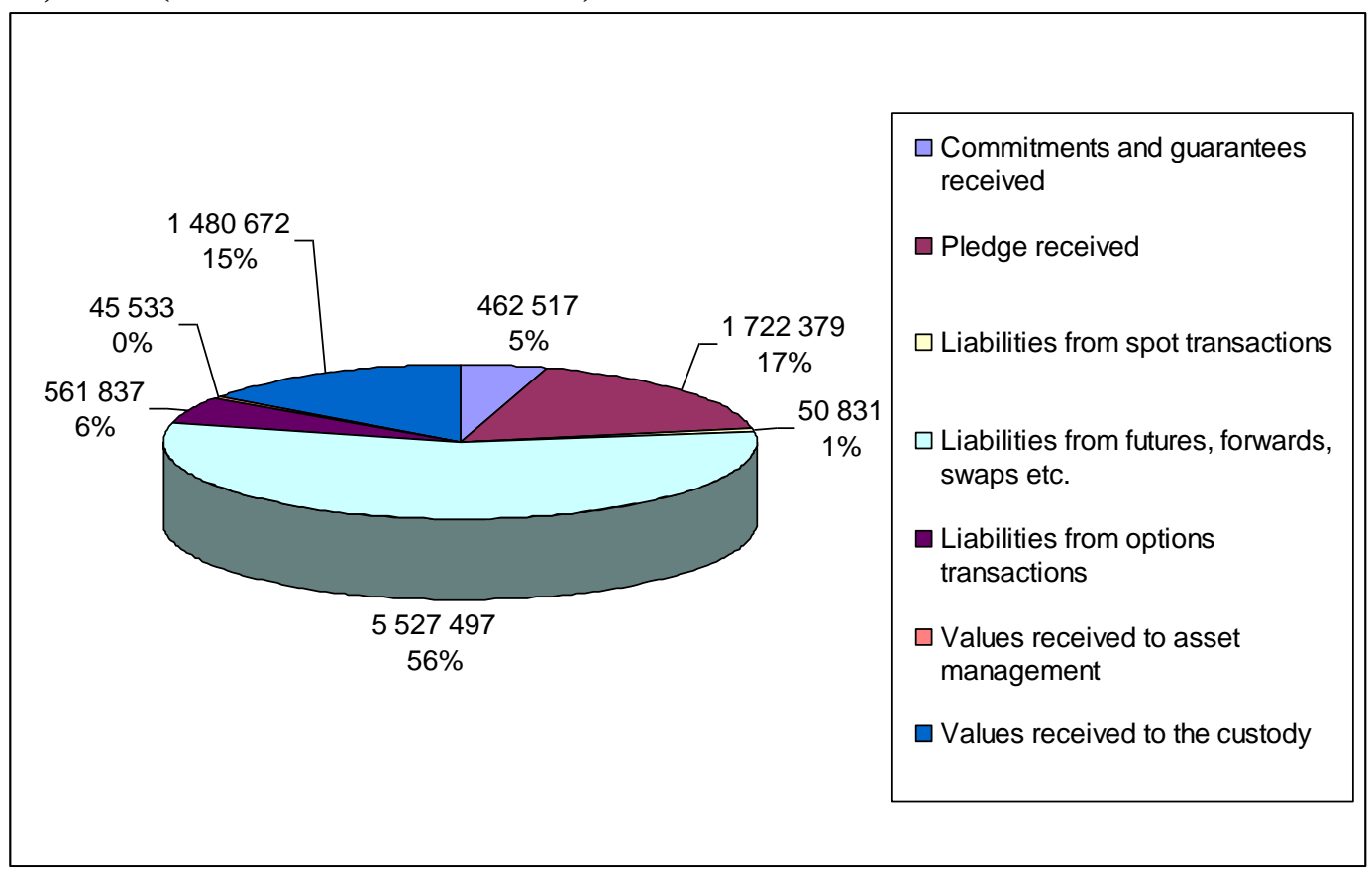

Source: own construction based on CNB's data

\section{Development of the off-balance sheet}

During several past years, the off-balance sheet had progressive tendency. This trend lasted until 2008. The OBS assets were of value of 4,641,842 millions of CZK at the end of 2004 . Four years later, their amount increased to 10,790,706 millions of CZK. The OBS liabilities registered similar trend. At the end of 2004 their amount reached 6,304,245 millions of CZK and four years later their amount was more than two times higher, i.e. 13,236,063 millions of CZK.

Fig. 3 Development of off-balance sheet of banking system in Czech Republic (in CZK millions)

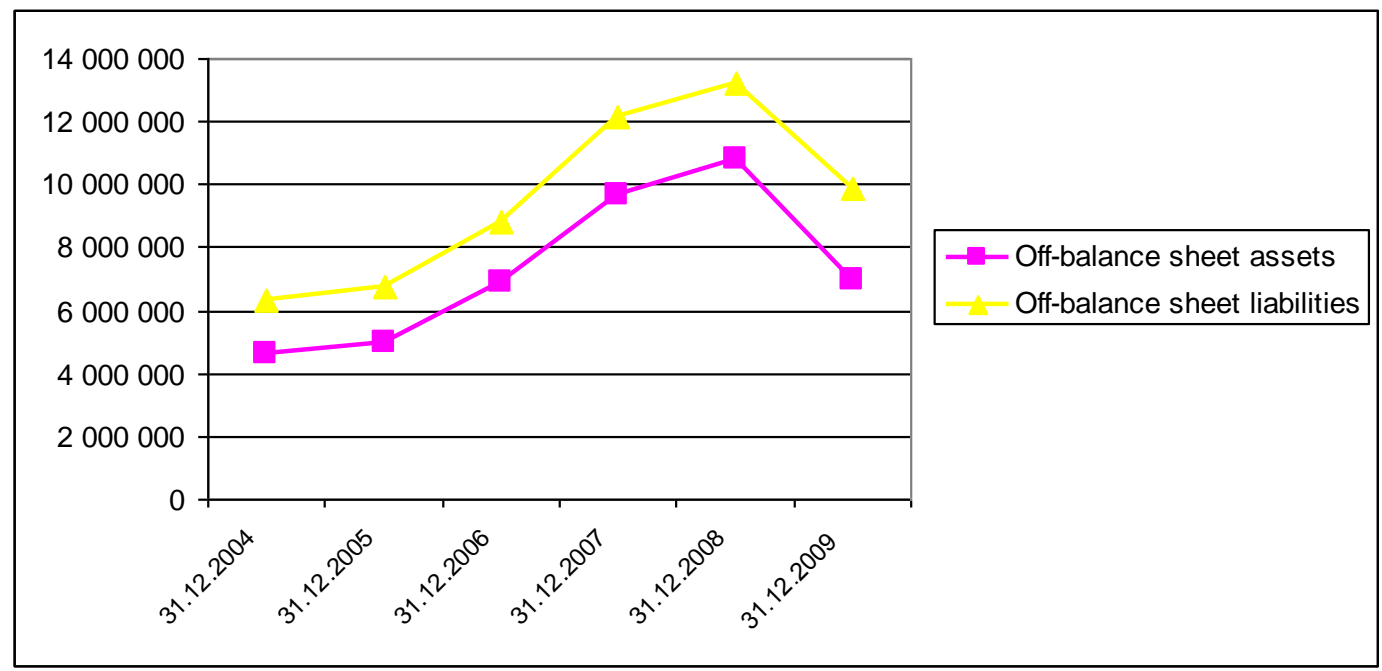

Source: own construction based on CNB's data 
During the following year, 2009, the OBS activities drop sharply and on December 31, 2009 their value did not reach the value of the end of 2007. The value of BOS assets was 6,941,578 millions of CZK, and the value of OBS liabilities was 9,851,267 millions of CZK.

For the OBS of the banking system in the Czech Republic it is typical that the value of OBS liabilities exceeds the value of OBS assets. The difference has been something about 2,000,000 to 3,000,000 millions of CZK since the end of 2004.

\section{Comparison of the off-balance sheet and the balance sheet}

Another characteristic feature of the banking off-balance sheet in the Czech Republic is its higher volume in comparison with the balance sheet. The proportion of OBS assets and liabilities in balance sheet assets and is presented in Figure 4.

Fig. 4 Proportion of OBS assets and OBS liabilities in balance sheet assets (in \%)

\begin{tabular}{|c|c|c|}
\hline Year & $\begin{array}{l}\text { The proportion of off-balance sheet } \\
\text { assets in balance sheet assets }\end{array}$ & $\begin{array}{l}\text { The proportion of off-balance sheet } \\
\text { liabilities in balance sheet assets }\end{array}$ \\
\hline 2004 & 176.12 & 239.20 \\
\hline 2005 & 169.20 & 227.63 \\
\hline 2006 & 217.93 & 279.83 \\
\hline 2007 & 257.19 & 323.18 \\
\hline 2008 & 266.80 & 327.26 \\
\hline 2009 & 169.62 & 141.92 \\
\hline
\end{tabular}

Source: own calculation based on CNB's data

The proportion is also known as OBS / $\mathrm{TA}^{7}$ ratio and is commonly used in scientific articles. Its applicability for comparison among foreign countries is limited, however, because of the different definition of the OBS activities. For curiosity, in 2000 the ratio was $35 \%$ in United Kingdom and only $13 \%$ in Italy. ${ }^{8}$

As we can see in the table above, it is interesting the year 2009, when the proportion fell sharply - especially in the case of OBS liabilities. This was caused by the decrease of the nominal value of the OBS assets and liabilities. The value of the balance sheet, on the contrary, held its rising tendency. The amount of the aggregate balance sheet at the end of 2008 was 4,044,477 millions of CZK and 4,092,382 millions of CZK at the end of 2009.

The development of OBS activities in comparison with balance sheet assets is the content of the following figure.

\footnotetext{
${ }^{7}$ Total assets.

${ }^{8}$ Girardone, C., Casu, B. An Analysis of the Relevance of Off-Balance Sheet Items in Explaining Productivity Change in European Banking. P. 14.
} 


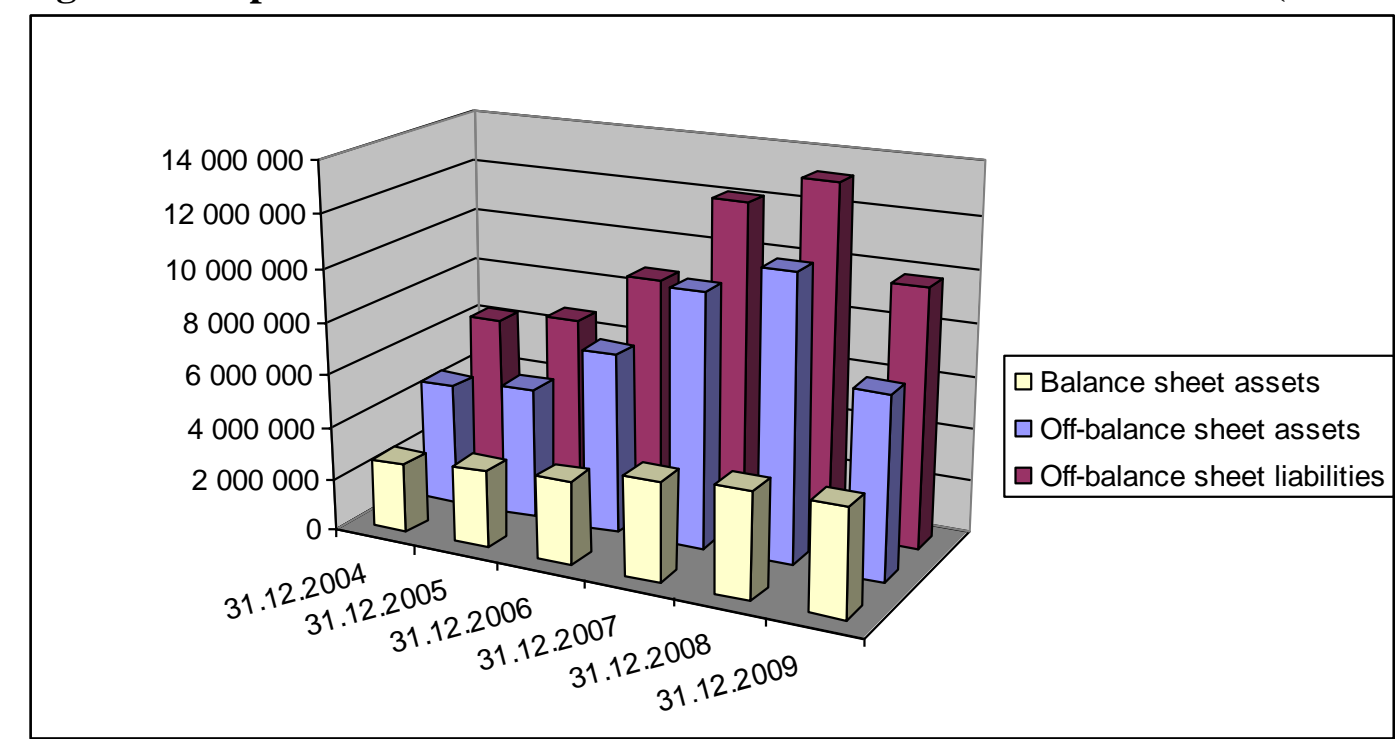

Source: own construction based on CNB's data

The progressive tendency, which has been typical since the 90s of the last century, can be explained by external pressure on commercial banks. Indeed, the banks are exposed increasingly higher competition from non-banking subjects (insurance companies, credit unions, brokers, ...). So as to be competitive, they have to develop new services (products) affecting off-balance sheet. ${ }^{9}$

In my opinion, there are more reasons for this increase. Particular, it is the different regulatory approach for balancing and off-balancing items. The OBS items are not seen as own assets or liabilities of the bank.

The rise of OBS activities has a positive impact on the economy of the banks. These activities create additional non-interest income.

\section{Profits of the off-balance sheet activities}

The banks have two basic forms of income - the interest income and the fee and commission income. The interest income come from lending (granted credits) which is the balance sheet activity. The fee and commission income is the income charged by the bank for services such as account management, payments, asset management or financial advisory.

So far, we have worked with the OBS activities reported in the accounting statements. The definition of OBS activities is wider. In principle, the OBS activities include all activities that do not act on the balance sheet. Except the accounting OBS assets and OBS liabilities, this means all types of services (payments, advisory, asset management, etc.). ${ }^{10}$ For these services, banks charge fees and commissions. Thus, as the income from OBS activities can be considered the fee and commission income.

If we examine the development of the OBS assets and the fee and commission income, we can see that during the years 2004 to 2008 both of them were gradually increasing and in 2009 they both fell.

\footnotetext{
${ }^{9}$ Půlpánová, S. Komerční bankovnictví v České republice. P. 68.

${ }^{10}$ This definition of OBS activities is commonly used in many scientific articles, including those from abroad.
} 
Fig. 6 Development of the fee and commission income and the OBS assets (in CZK millions)

\begin{tabular}{|c|c|c|c|c|c|c|}
\hline & 2004 & 2005 & 2006 & 2007 & 2008 & 2009 \\
\hline \multicolumn{7}{|c|}{ Fee and commission income } \\
\hline $\begin{array}{l}\text { Fee and } \\
\text { commission } \\
\text { income }\end{array}$ & 38,085 & 38,899 & 41,093 & 44,830 & 46,779 & 46,755 \\
\hline $\begin{array}{l}\text { Growth in } \\
\%\end{array}$ & - & 2.14 & 5.64 & 9.09 & 4.35 & -0.05 \\
\hline \multicolumn{7}{|c|}{ Off-balance sheet assets } \\
\hline OBS assets & $4,641,842$ & $4,998,926$ & $6,868,595$ & $9,646,375$ & $10,790,706$ & $6,941,578$ \\
\hline $\begin{array}{l}\text { Growth in } \\
\%\end{array}$ & - & 7.69 & 37.40 & 40.44 & 11.86 & -35.67 \\
\hline
\end{tabular}

Source: own construction based on CNB's data

But the growth rate of each of them was not the same. The growth rate till 2008 of the OBS assets had been much higher. Similarly, the decline in 2009 was much deeper in the case of the OBS assets than the one of the fee and commission income. Thanks to this, the income in the form of received fees and commission per unit of off-balance sheet assets had been declining through the years 2004 to 2008.

Fig. 7 Fee and commission income on OBS assets (in CZK millions)

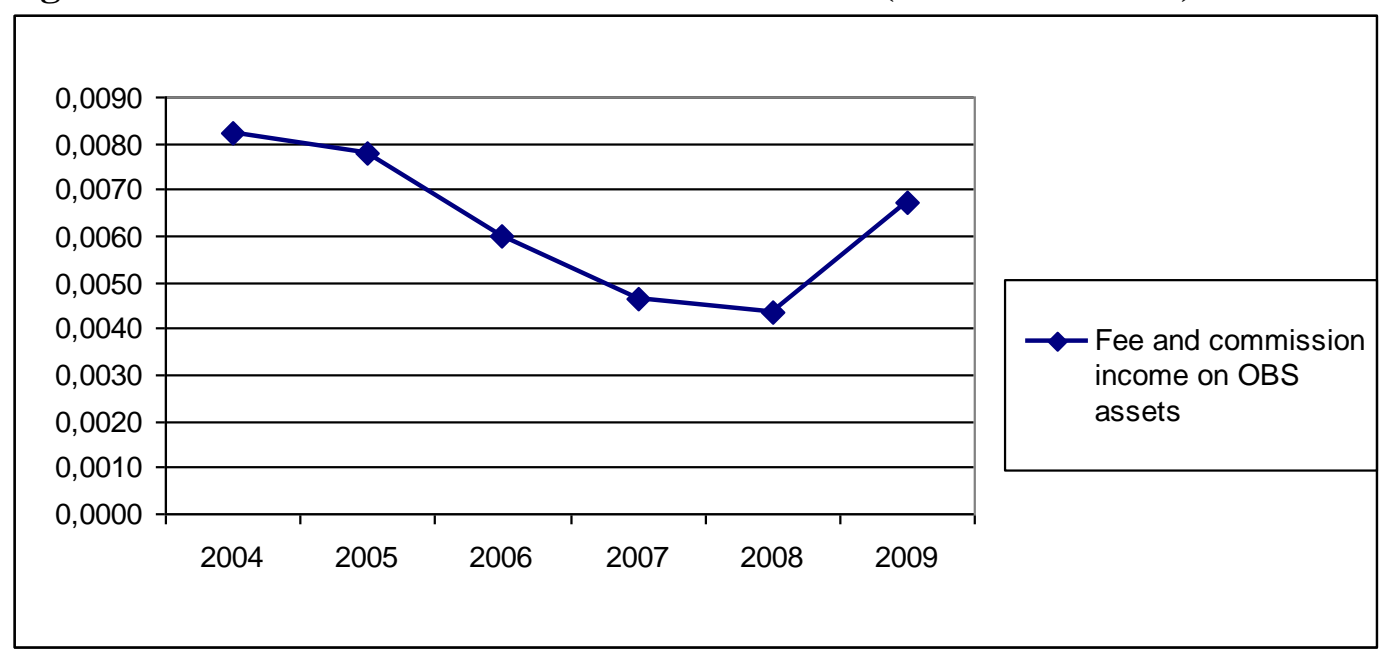

Source: own construction based on CNB's data

While in 2004 the income on OBS assets was about $0.0082 \mathrm{CZK}$, in 2008 it was only 0.0043 CZK. In 2009 it increased to 0.0067 CZK. However, this was not even the level of 2005.

This ratio can be considered as an analogy of ROA which is used to asses the efficiency of banking business. But we have to bear in mind that there are some important differences:

- in ROA we work with the profit of the bank but here we work just with the income (we do not take into account the costs);

- the fee and commission income is not the correct income of the OBS assets.

\section{Off-balance sheet in the context of the economy output}

Another interesting point of view on OBS activities is the view in the context of the economic output - Gross domestic product (GDP). 
During examined period, the Czech economy had been in a good condition since 2004 till 2007. The output of the economy was every year higher with increasing rate of growth. In 2008, the output increased again but the growth rate declined. The GDP reached its top at level 3,689 billions of CZK while the next year it was only 3,628 billions of CZK. The decline was caused by the financial crisis which originated in 2007 in USA and then spread to other countries in the world.

In comparison of the GDP with the OBS assets we can see that the financial crisis affected the OBS assets much harder. The decline of the OBS assets was deeper. It was caused especially by the lowest level of the nominal value of receivables from futures, forward, swap and options transactions.

Fig. 8 Development of the off-balance sheet assets and GDP (in CZK billions)

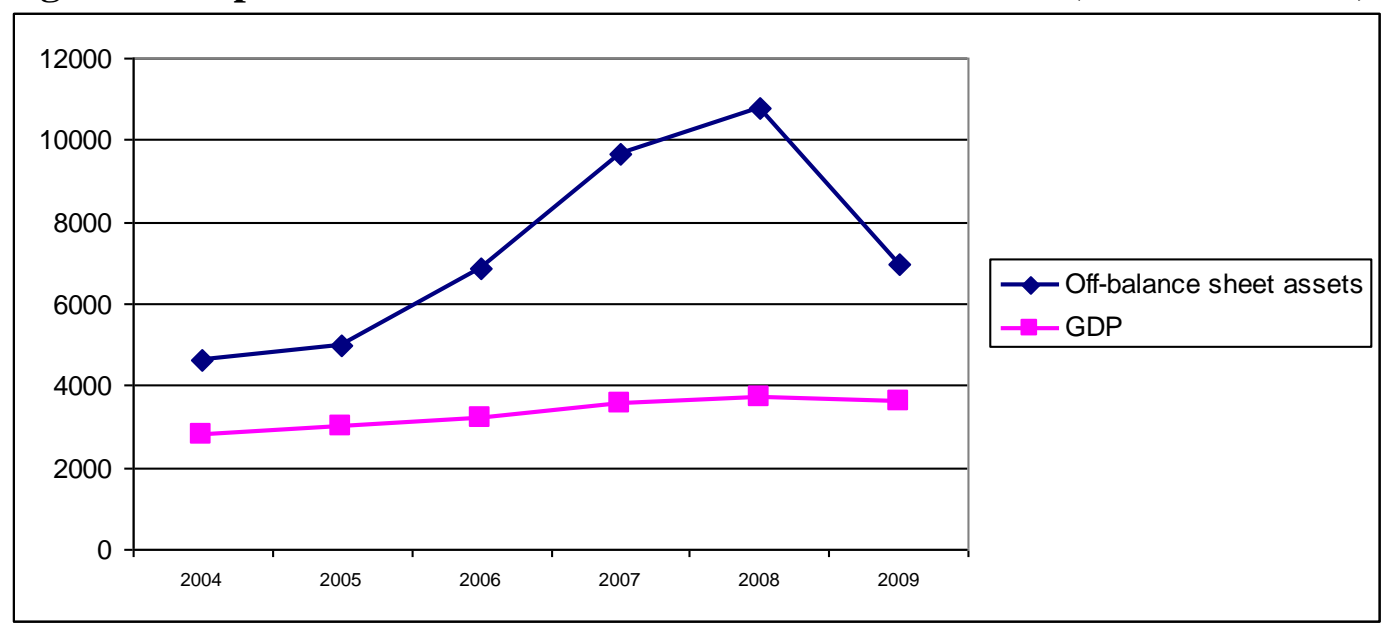

Source: own construction based on data of CNB and Ministry of Finance of the CR

For better assessment of development of OBS assets with respect to GDP, we can use correlation analysis. The correlation coefficient is 0.823 which means that the OBS assets development is similar to development of GDP. Development of OBS assets is closely linked to GDP.

In author's opinion, this is caused by the fact that when GDP falls, banks limit their offbalance sheet activities. That is because of declining demand for bank services such as bank guarantees, open credit lines etc. Moreover, banks themselves do not want to take risks when economy goes wrong. Counterpart credit risk rises and banks behave prudently in off-balance sheet operations (limit bank guarantees and forward or futures operations etc.).

Figure 9 shows correlation analysis for years 2004 to 2009 . 
Fig. 9 Correlation of HDP and OBS assets

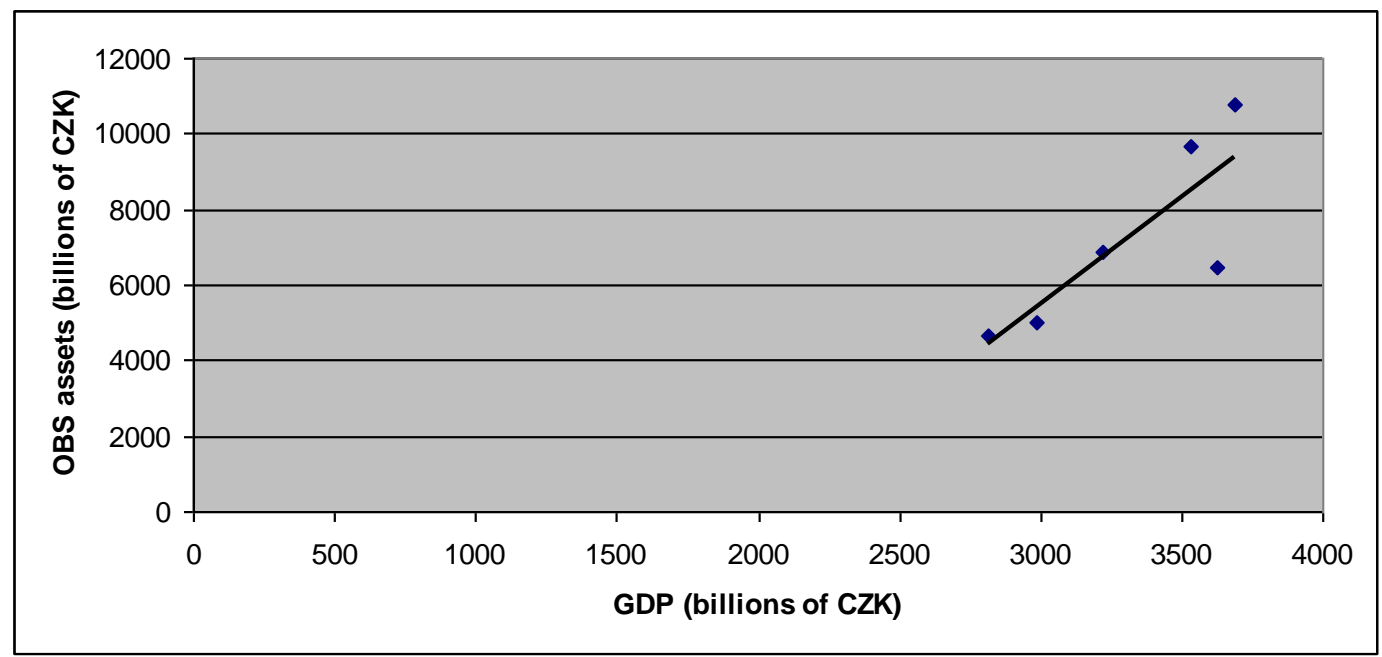

Source: own construction based on data of CNB and Ministry of Finance of the CR

The annual rate of both examined quantities is showed in the next figure.

Fig. 10 Fee and commission income on OBS assets (in \%)

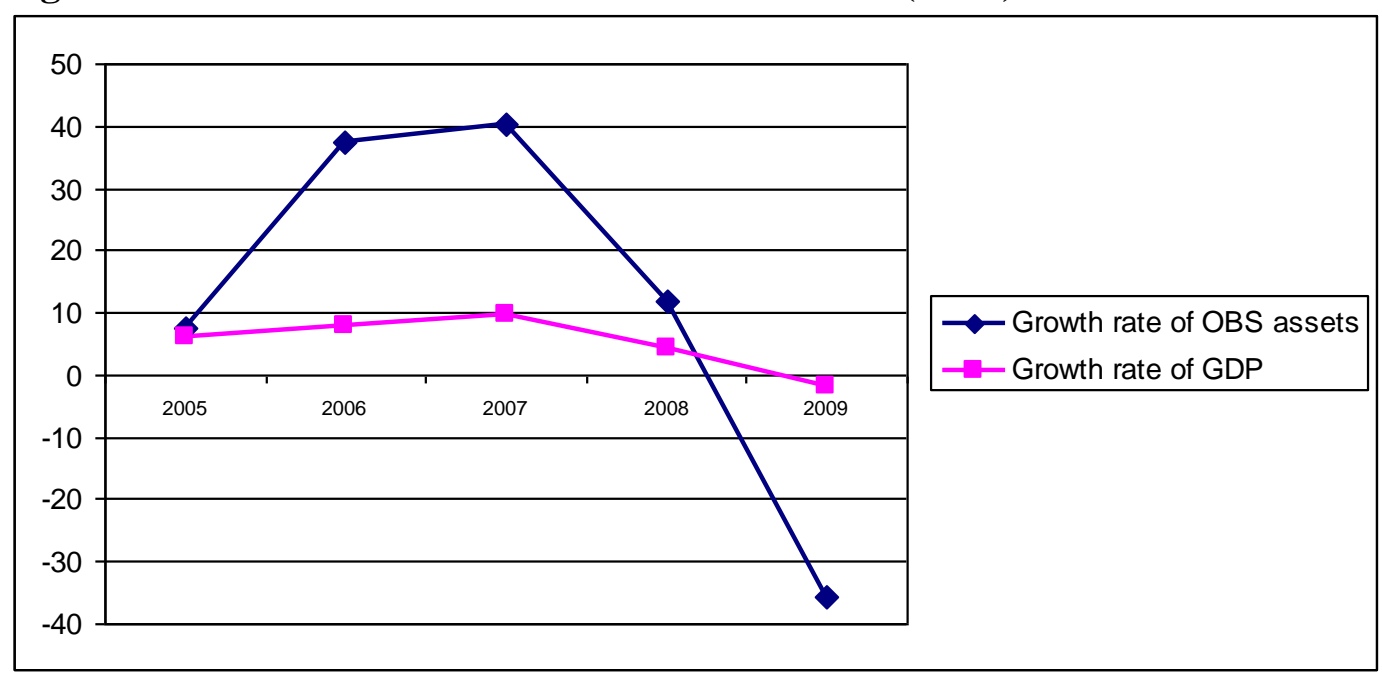

Source: own construction based on data of CNB and Ministry of Finance of the CR

Examining the Figure 8, we can see an interesting feature of the Czech banking sector. The nominal value of OBS assets of commercial banks is several times higher than the output of the whole economy.

Although the nominal value of the OBS assets fell sharply in 2009, the income from OBS activities remained almost unchanged despite crisis. The fall of the fee and commission income was very mild.

For better comparison, the development of the fee and commission income and the GDP is shown in the following figure. 
Fig. 11 Development of the fee and commission income and the GDP

\begin{tabular}{|c|c|c|c|c|c|c|}
\hline & 2004 & 2005 & 2006 & 2007 & 2008 & 2009 \\
\hline \multicolumn{7}{|c|}{ Fee and commission income (in CZK millions) } \\
\hline $\begin{array}{l}\text { Fee and } \\
\text { commission } \\
\text { income }\end{array}$ & 38,085 & 38,899 & 41,093 & 44,830 & 46,779 & 46,755 \\
\hline $\begin{array}{l}\text { Growth in } \\
\%\end{array}$ & - & 2.14 & 5.64 & 9.09 & 4.35 & -0.05 \\
\hline \multicolumn{7}{|c|}{ GDP (in CZK billions) } \\
\hline GDP & 2,815 & 2,984 & 3,222 & 3,535 & 3,689 & 3,628 \\
\hline $\begin{array}{l}\text { Growth in } \\
\%\end{array}$ & 9.20 & 6.00 & 8.00 & 9.70 & 4.30 & -1.70 \\
\hline
\end{tabular}

Source: own construction based on data of CNB and Ministry of Finance of the CR

As can see, they both reached the top in 2008 and at the end of 2009 suffered a decline. But the growth and subsequent decrease were not the same. In 2005 to 2007 the growth of the GDP was higher. In the next year 2008 the economic growth slowed and was slightly lower than the growth of the fee and commission income. In 2009 the GDP fell by 1.7 per cent while the fee and commission income remained almost the same as the previous year 2008. Its decline was only about 0.05 per cent.

So, even if the economy did not go well and passed through the times of crises, the banking income in the form of received fees and commissions was almost unchanged. Czech banks were able to keep their income despite the crisis.

But not only fee and commission income proved the good condition of Czech banks during the crisis. Beside this, the Czech banks showed relatively high profits for 2009. For some of them the profits were even record.

\section{Conclusion}

As demonstrated by the survey, the structure of the off-balance sheet of the Czech banking sector is made up mainly by the receivables and liabilities from futures, forward and swap transactions. In 2009, the receivables from these transactions took share about $80 \%$ of total OBS assets and the share of the liabilities from these transactions was about $56 \%$ of total OBS liabilities.

During years 2004 to 2008 the nominal value of OBS activities had been growing. In 2008, both OBS assets and OBS liabilities got to their top while their value was 10,790,706 millions of CZK on the side of OBS assets and 13,236,063 millions of CZK on the side of OBS liabilities.

The characteristic feature for the Czech banking OBS activities is that the amount of OBS liabilities is higher than the one of the OBS assets. During the examined period the difference had been from 2,000,000 to 3,000,000 millions of CZK.

Among the characteristic features of Czech OBS activities can be included prevalence of OBS activities over balance sheet activities in their nominal value. In comparison of the off-balance sheet with its balance counterpart, we can see that the nominal value of the OBS assets or liabilities is higher than the total of the balance sheet. In 2009, the OBS assets were equal to $169.62 \%$ of the balance sheet and the OBS liabilities were equal to $141.92 \%$. 
In 2004 the income per unit of the OBS asset was $0.0082 \mathrm{CZK}$ and in 2008 it was only about $0.0043 \mathrm{CZK}$. The next year 2009 the profitability improved and the income per unit was $0.0067 \mathrm{CZK}$.

The off-balance sheet in the context of the macroeconomic output has also several interesting features. The nominal value of OBS assets is several times higher than the output of the whole Czech economy - GDP. In 2008, the GDP was 3,689 billions of CZK but the amount of the OBS assets was circa three times higher, 10,791 billions of CZK specifically. In 2009, the gap narrowed. The GDP reached 3,628 billions of CZK and the OBS assets 6,942 billions of CZK.

From 2004 to 2008 both quantities, GDP and OBS assets, had been gradually increasing. But the growth rate was far higher in the terms of the OBS assets. In 2007, the growth rate of OBS assets reached even $40 \%$, while the growth rate of GDP was less than $10 \%$. In 2009, the rate of growth of them both was negative. The decline in growth rate on the side of OBS assets was much harder than on the side of GDP. The OBS assets fell by about $36 \%$ but the GDP fell by $1.7 \%$ only.

If we compare the income from OBS activities with the economic output, we can see that the banks went well in the crisis. They were able to keep their fee and commission income despite worsen economic conditions. In 2009, the profitability of the OBS activities remained almost unchanged in comparison with the previous year.

\section{References}

[1] CZECH NATIONAL BANK. Financial market supervision report 2008. [online]. Retrieved from http://www.cnb.cz/cs/dohled_fin_trh/dnft_zpravy/download/dnft_2008_cz.pdf

[2] CZECH NATIONAL BANK. Table 2 Balance sheet statement of the banking sector $2 a$ Assets. [online]. Retrieved from http://www.cnb.cz/en/financial_market_supervision/basic_indicators_fin_sector/banks/ bs_ukazatele_tab02a.html

[3] CZECH NATIONAL BANK. Table 2 Balance sheet statements of the banking sector$2 b$ Liabilities and equity. [online]. Retrieved from http://www.cnb.cz/en/financial_market_supervision/basic_indicators_fin_sector/banks/ bs_ukazatele_tab02b.html

[4] CZECH NATIONAL BANK. Table 3 Off-balance sheet assets of the banking sector. [online]. Retrieved from http://www.cnb.cz/en/financial_market_supervision/basic_indicators_fin_sector/banks/ bs_ukazatele_tab03.html

[5] CZECH NATIONAL BANK. Table 4 Income Statement of the banking sector - 4aAbsolute indicators. [online]. Retrieved from http://www.cnb.cz/cs/dohled_financni_trh/souhrnne_informace_fin_trhy/zakladni_ukaz atele_fin_trhu/banky/bs_ukazatele_tab04a.html

[6] Decree No. 123/2007 Coll. of 15 May 2007, stipulating the prudential rules for banks, credit unions and investment firms, as amended by Decree No. 282/2008 Coll., divided into parts, with links to official information and to questions and answers. 
[7] Decree No. 501/2002 Coll., implementing certain provisions of Act No. 563/1991 Coll, on Accounting, as amended, for accounting units that are banks and other financial institutions.

[8] DVOŘÁK, P. Bankovnictví pro bankéře a klienty. 3rd ed. Prague: Linde, 2005. 681 p. ISBN 80-720-1515X.

[9] DVOŘÁK, P. Deriváty. $2^{\text {nd }}$ ed. Prague: Oeconomica, 2008. 297 p. ISBN 978-80-2451435-2.

[10] GIRARDONE, C., CASU, B. An Analysis of the Relevance of Off-Balance Sheet Items in Explaining Productivity Change in European Banking. [online]. Retrieved from http://www.cass.city.ac.uk/conferences/mmf2004/files/Giradone\%26Casu.pdf

[11] MINISTRY OF FINANCE OF THE CZECH REPUBLIC. Table C.1 Economic Output. [online]. Retrieved from

http://www.mfcr.cz/cps/rde/xchg/mfcr/xsl/macroeconomic_56440.html

[12] POLOUČEK, S. Penize, banky, finanční trhy. $1^{\text {st }}$ ed. Praha: C. H. Beck, 2009. 415 p. ISBN 9788074001529.

[13] OLŠOVSKÝ, R. Compilation of statistical data on new financial instruments: the case of the Czech Republic. [online]. Retrieved from http://www.bis.org/ifc/publ/ifcb31s.pdf

[14] PŮlPÁNOVÁ, S. Komerčni bankovnictvi v České republice. $1^{\text {st }}$ ed. Prague: Oeconomica, 2007. 338 p. ISBN 978-80-245-1180-1.

\section{JEL Classification: G21}

\section{Ing. Veronika Bučková, Ph.D.}

Department of economic, legal and social sciences

College of Logistics

Palackého 1381/25

75002 Přerov

Czech Republic

veronika.buckova@vslg.cz 